Portland State University

PDXScholar

2018

Invisible Walls Mapping Residential Segregation In Portland

\author{
Katrine Barber \\ Portland State University, barberk@pdx.edu
}

Follow this and additional works at: https://pdxscholar.library.pdx.edu/hist_fac

Part of the History Commons

Let us know how access to this document benefits you.

Citation Details

Barber, K., Hart, L., Jewell, C., Miller, M., \& Smith, G. (2018). Invisible Walls: Mapping Residential Segregation In Portland. Oregon Historical Quarterly, 119(3), 400-405.

This Article is brought to you for free and open access. It has been accepted for inclusion in History Faculty Publications and Presentations by an authorized administrator of PDXScholar. Please contact us if we can make this document more accessible: pdxscholar@pdx.edu. 


\section{Invisible Walls}

\section{Mapping Residential Segregation In Portland}

\section{LOCAL HISTORY SPOTLIGHT}

by Katrine Barber, Lily Hart, Curtis Jewell, Madelyn Miller, and Greta Smith

THE 1928 DEED for a house in Portland's Palatine Hill neighborhood specifies that "no person of African, Asiatic or Mongolian descent shall be allowed to purchase, own or lease said premise." In the first half of the twentieth century, Portland joined cities across the nation in using racially restrictive covenants to implement residential segregation. Although the U.S. Supreme Court's 1948 Shelley $v$. Kraemer ruling determined that such covenants violated the Equal Protection Clause of the Fourteenth Amendment, making them unenforceable, racial covenants have not been removed from the chains of title and still appear in the deeds of many Portland homes. ${ }^{2}$

Racially restrictive covenants are important markers of the exclusion of minority populations, including Indigenous people, immigrants considered non-white, and especially African Americans, from a housing market that privileged white buyers. Unlike excluded communities, Portlanders who did not face restrictions - primarily whites - could build wealth through the equity in their homes, which they could pass down through generations. The legacies of housing restrictions reverberate into the present; today, African Americans hold a mere 10 percent of the median household wealth held by white families. This is a result of decades of federal and local policies as well as realtor guidelines that hobbled the ability of people of color to purchase and invest in properties. ${ }^{3}$ As in other cities, residential segregation in Portland did not go uncontested. Members of the city's African American community organized against discrimination in housing, education, employment, and public accommodation. ${ }^{4}$

In spring 2018, students in a Portland State University (PSU) course set out to understand how barriers to home ownership among families of color - as well as resistance to those barriers - have historical and continuing influence on our city. Over the previous year, a conversation with Ryan Curren of Portland's Bureau of Planning and Sustainability, who had contacted PSU's History Department 


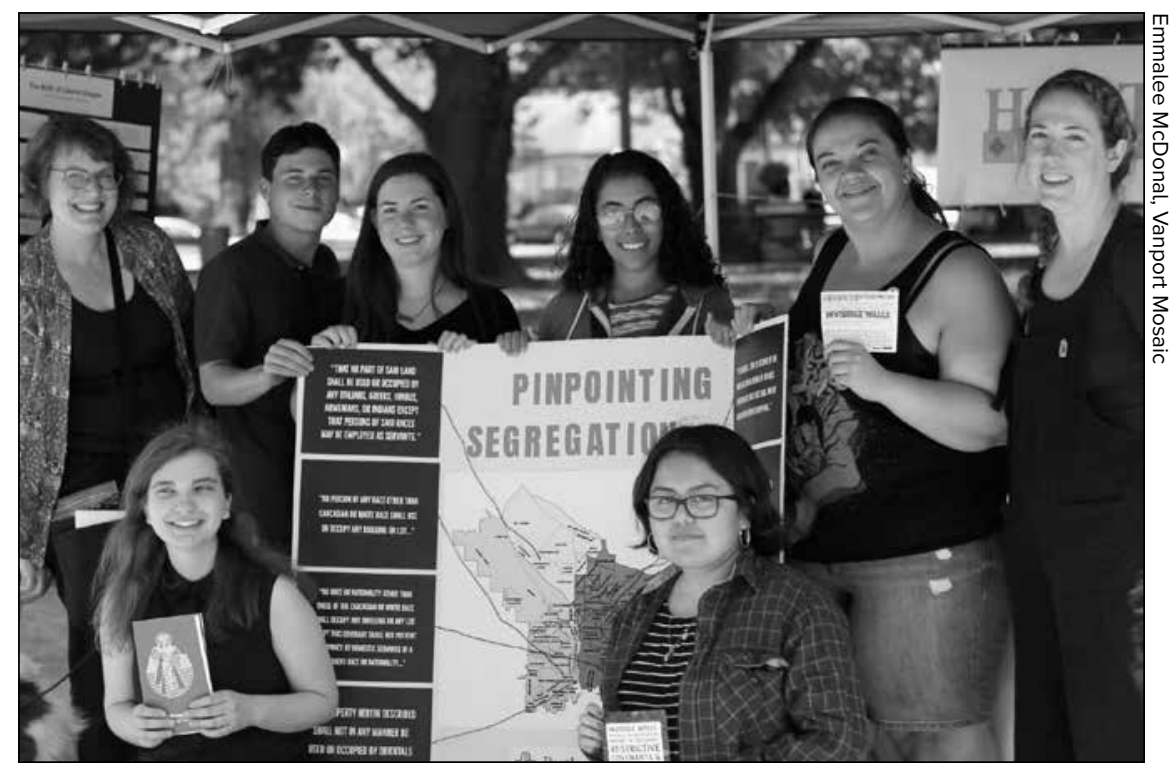

PORTLAND STATE UNIVERSITY students from the History Department and the University Honors College developed an interdisciplinary and multimodal exhibit that addressed the many ways residential segregation has left a lasting impact on Portland. Students are shown here at one of the stops for the exhibit, the Vanport Mosaic Festival. From left to right, Katrine Barber, Adian Kolar, Madelyn Miller, Autymn Langford, Crystal Romero, Greta Smith. Lily Hart and Karen Torres-Olguin are in front.

for research assistance, gave rise to the crowdsourcing of deeds holding restrictive covenants, the PSU class described here, and a partnership with the Vanport Mosaic (vanportmosaic. org) - a local nonprofit that works to amplify, honor, and preserve the silenced histories of the Pacific Northwest. Inspired by "Mapping Inequality: Redlining in New Deal America," a collaborative effort among four universities to digitize Home Owners' Loan Corporation (HOLC) maps (the origins of "redlining"), and "Segregated Seattle," a special section of the University of Washington's Seattle Civil Rights and Labor History Project, which documents urban segregation through restrictive covenants, we wondered, "Could we do something similar for Portland?"

Fourteen PSU students in a public history class (eleven from the Urban Honors College, three undergraduate history students, and one history graduate student) collaborated with the City of Portland and Vanport Mosaic to document residential segregation in Portland. We sought to make visible the invisible walls constructed through racially restrictive covenants by collecting evidence in the form of deeds and then by sharing our findings with the public. 


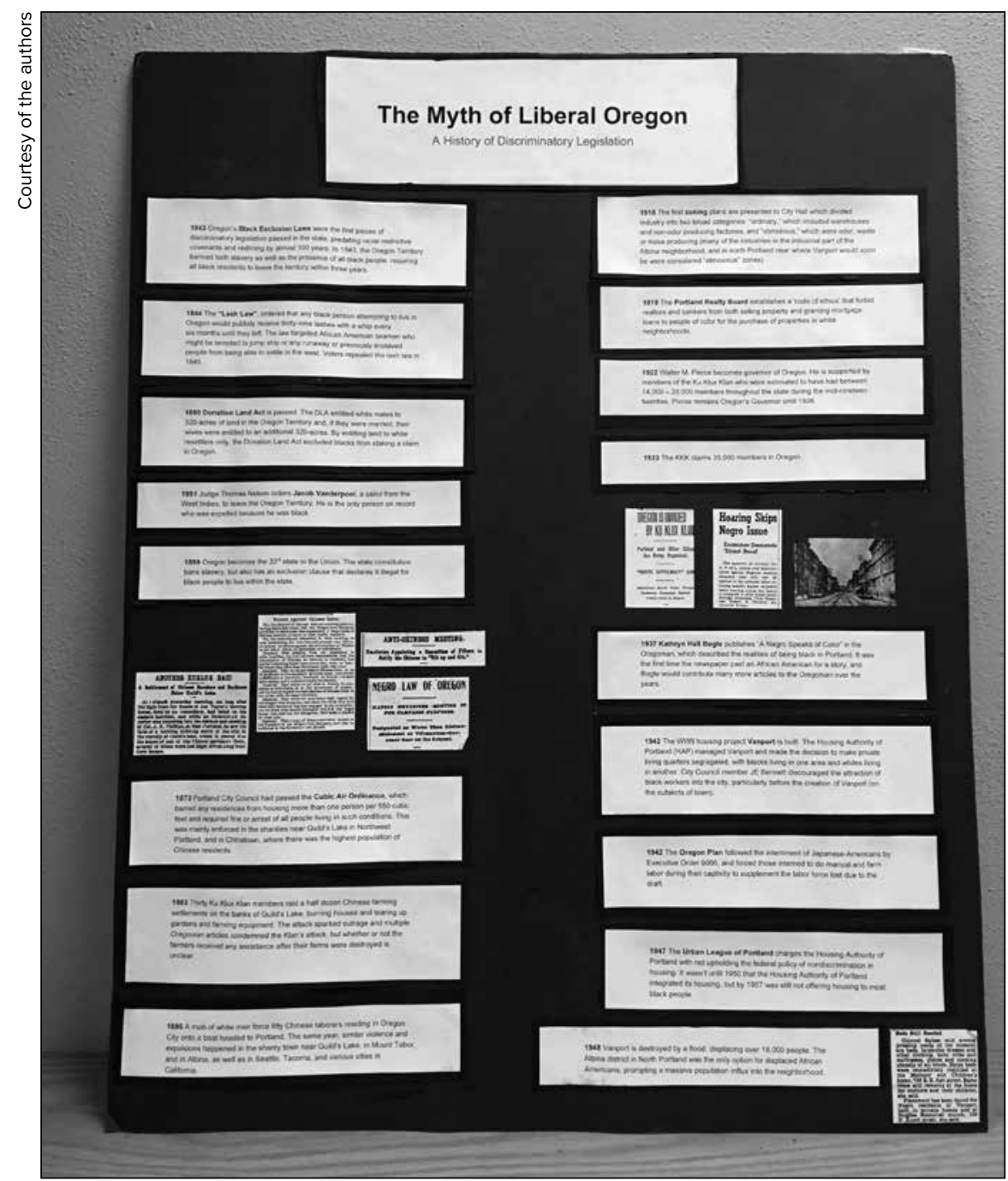

THE POSTER "The Myth of Liberal Oregon" featured a timeline of legislation and events in Oregon history that counter the narrative of the state as a liberal corner of the country. The title was chosen to be intentionally attention-grabbing and evocative, and was effective at drawing passers by to the exhibit at each event.

During the first few weeks of the term, students poured over historic deeds accessed through the Multnomah County Archives. But our most effective research method involved crowdsourcing deeds from interested homeowners. Initial publicity about the project, tied to the fiftieth anniversary of the 1968 Fair Housing Act in March 2018, netted some twenty deeds with racial restrictions. Further outreach two months later at the Vanport Mosaic 
Festival and at PSU's Archaeology Roadshow more than doubled that number. Through these events, we provided historical context to community audiences, while they in turn provided essential evidence to us. Ultimately, every deed will contribute to a City of Portland mapping project.

We also found other ways to document residential segregation in Portland. Advertisements for housing and brochures that publicized new developments often included direct and indirect language regarding racial restrictions. Laurelhurst was a "most wisely restricted residence park," for example, and lots on Hancock and Tillamook streets were "restricted residence sites in a district of nice homes." 5 Descriptions such as "exclusive" indicated areas that likely included racial restrictions.

Central to the course was sharing our findings with interested audiences. Our first opportunity was by invitation to another PSU course with freshmen who were studying the contemporary housing crisis. Together we explored how previous legislative decisions perpetuated oppressive trends. After testing ideas with fellow students, we were ready to take them to larger audiences.

Over the Memorial Day weekend, we staffed a table at the Vanport Mosaic Festival - six days of memory activism opportunities commemorating the seventieth anniversary of the Vanport flood and the fiftieth anniversary of the Fair Housing Act through screenings, live performances, tours, exhibits, and community engagement initiatives. It was a great opportunity for us to bring our work into a public forum. We featured several display boards, one of which highlighted quotes from deed restrictions and a map that indicated the properties that the deeds represented. We asked visitors to place a pin in the map where they lived, hoping to encourage them to think critically about their own housing experiences in relation to these areas. Did they fall within redlined districts, where it was historically difficult for residents to secure mortgages and home loans? Or was their home in a neighborhood covered by racially restrictive covenants?

For a display board titled "The Myth of Liberal Oregon," we tied episodes of residential segregation to a broader history of Oregon race relations, developing a timeline of legislation and events from Oregon Territory's "Lash Laws" to the disparate relief following the 1948 Vanport Flood to more recent episodes of displacement and gentrification. A third display focused on Portlanders' resistance to racial injustice in financial lending and the housing market. Anticipating that the most common question the public would have at these events would be, "How do we find out if my title deed has racial restrictions?," we offered a guide for locating deeds as well as where to look for restrictive covenants within them. Three zines that visitors could take with them tracked the history of residential segregation in Portland and the nation. These materials, as well as a podcast that documents our journey, can be found on our website (restrictedpdx.wordpress. com). The following weekend we did it all again, but this time at the annual PSU Archaeology Roadshow. 


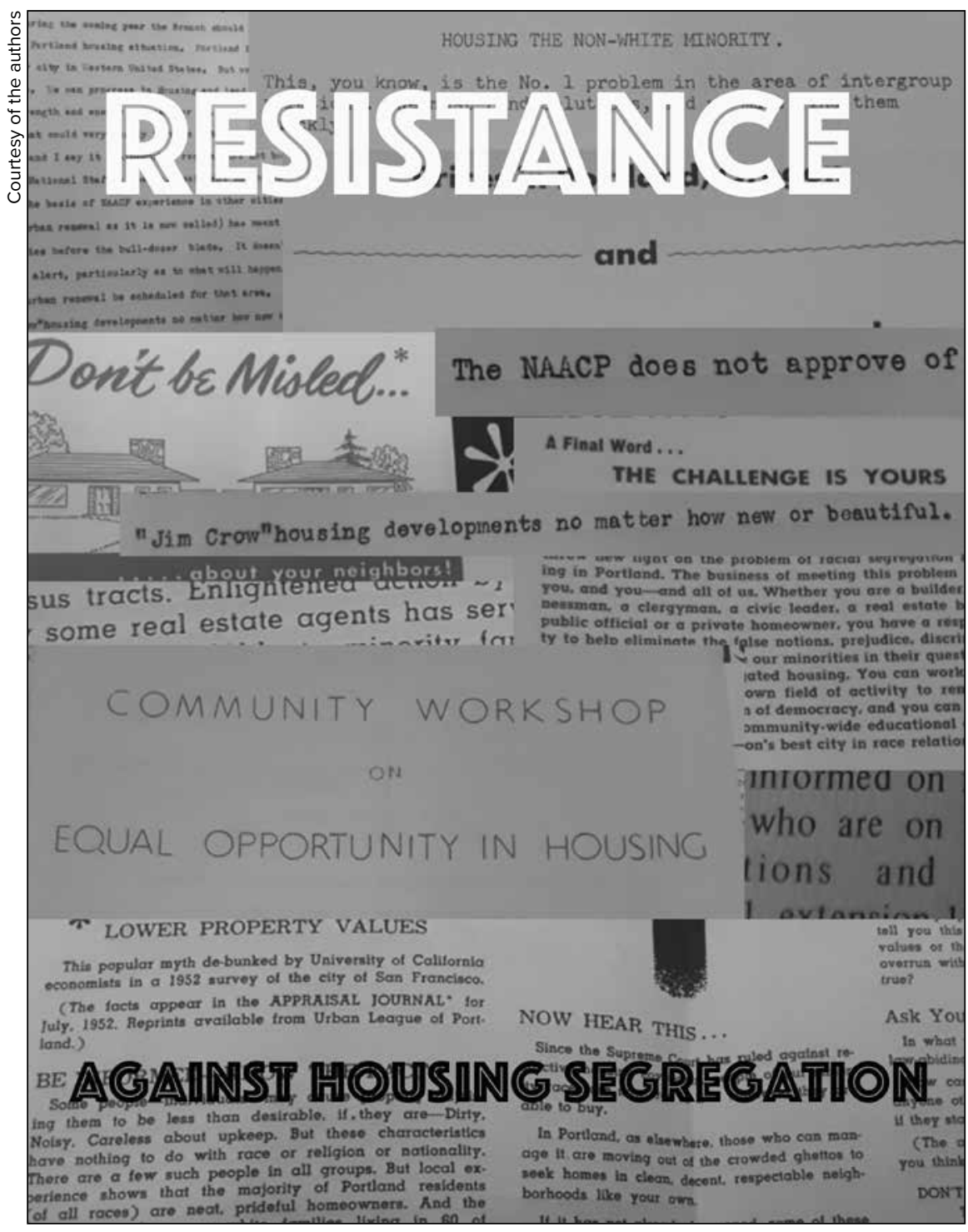

STUDENTS WROTE and illustrated three zines that covered residential segregation in the United States, what residential segregation looked like in Portland, and local resistance to it in the city. These zines were takeaways for Vanport Mosaic and the PSU Anthropology Roadshow visitors. They are available at the course website: restrictedpdx.wordpress.com.

The importance of this work was demonstrated to us as we conducted the various events. At the Vanport
Mosaic Festival, multiple people came up to us with deeds, having heard about the project through local news 
coverage, and expressed relief: they now had a place to put this information. These visitors generally had some prior knowledge of restrictive covenants, but they still found answers to their questions about patterns of segregation and its persistence in Portland. At the PSU Archaeology Roadshow, the audience was more varied, with many visitors wandering in from the nearby farmers' market. They were often learning about Portland's residential segregation for the first time as they engaged us in meaningful conversation.

By documenting racially restrictive covenants, we revealed the many ways that people of color have been denied access to property in Portland, how they navigated restrictions to purchasing homes, and the ongoing legacies of housing inequality in our community. Although the class ended in June, we are still collecting deeds with racial restrictions in them. Does your deed include racially restrictive language? If you don't know but want to find out, check out our deed research guide at restrictedpdx.wordpress.com. If you have a deed you would like to share with us, we'd love to see it. You can send it to pdxhst@ pdx.edu.

\section{NOTES}

This article has been collaboratively written by the course instructor, a community partner, and three students in the course, in keeping with the collaborative structure of the project.

1. Conditions and Restrictions affecting Palatine Hill by deed recorded February 3, 1928, in Deed Book 1122, page 339, Multnomah County Division of Assessment and Taxation, Portland, Oregon.

2. Recently, the Oregon State Legislature passed House Bill 4134, which makes it easier for home owners to remove discriminatory language from their deeds without fee through the county circuit court. Christen McCurdy, "New Law Makes it Easier to Remove Racist Restrictions from Property Deeds," Skanner News, March 1, 2018.

3. According to Richard Rothstein, "Median White family income is now about $\$ 60,000$, while median black family income is about $\$ 37,000-$ about 60 percent as much. You might expect that the ratio of black to white household wealth would be similar. But median white household wealth (assets minus liabilities) is about $\$ 134,000$, while median black household wealth is about $\$ 11,000$ - less than 10 percent as much." Richard Rothstein, The Color of Law: A Forgotten History of How Our Government Segregated America (New York: Liveright a division of WW Norton Publishing, 2017), 184. For information about how housing policy has affected African Americans in Portland, see Karen Gibson, "Bleeding Albina: A History of Community Disinvestment, 1940-2000," Transforming Anthropology, 15:1 (April 2007): 3-25.

4. See Melissa Cornelius Lang, “'A place under the sun': African American Resistance to Housing Exclusion," Oregon Historical Quarterly 119:3 (Fall 2018): 365-75.

5. La Grande Evening Observer, July 15, 1910, 6; Oregonian, September 13, 1912, p. 17. 